\title{
Revista Agroanalysis: a trajetória da afirmação do "agronegócio" e de consagração de seus agentes
}

\author{
Débora Franco Lerrer'
}

Resumo: A análise de dez anos de edições mensais da revista Agroanalysis (1994 a 2004), demonstra o processo de afirmação do termo agronegócio e do grupo de interesse, responsável por sua divulgação, liderado por Roberto Rodrigues, primeiro Ministro da Agricultura do Governo Lula. Esta trajetória de consagração se deve ao trabalho coletivo de representantes dos setores dominantes do campo e intelectuais que, diante das transformações econômicas e políticas que atingiam o meio rural, como o avanço da luta pela reforma agrária e o significativo aumento da rentabilidade das exportações de commodities, compartilham a percepção da necessidade de mudar a "imagem antiga" do setor perante a opinião pública.

Palavra-chave: agronegócio, luta pela reforma agrária, opinião pública

\section{Consolidation of agribusiness: its trajectory and agents on Agroanalysis Magazine}

Abstract: The ten-year analysis of monthly issues of Agroanalysis magazine (1994 to 2004) demonstrates the process of affirming the term agribusiness and the interest

\footnotetext{
1 Programa de Pós-Graduação de Ciências Sociais em Desenvolvimento Agricultura e Sociedade da Universidade Federal Rural do Rio de Janeiro (CPDA/UFRRJ) - Rio de Janeiro - Brasil - debora.lerrer. cpda@gmail.com
} 
group, responsible for its dissemination, led by Roberto Rodrigues, the first Minister of Agriculture of Lula Governement. This trajectory of consecration is due of the collective work of representatives of the rural dominant sectors and intellectuals who, in the face of economic and political transformations affecting the rural areas, such as the advance of the struggle for agrarian reform and the significant increase in export profitability of commodities, share the perception of the need to change the "old image" of the sector before public opinion.

Keywords: agribusiness, struggle for agrarian reform, public opinion

\section{Introdução}

As edições da revista Agroanalysis, publicadas de setembro de 1994 até dezembro de 2004, fornecem um material privilegiado para se delinear a trajetória da emergência do termo agronegócio, de como foi se constituindo e se legitimando progressivamente como categoria de classificação de uma determinada realidade social, mediante o trabalho coletivo de alguns intelectuais, pesquisadores e lideranças do patronato rural brasileiro. O objetivo deste artigo é descrever como o termo "agronegócio" passou a ser usado dentro desta publicação vinculada ao Instituto Brasileiro de Economia (IBRE), da Fundação Getúlio Vargas (FGV), durante esta década específica ${ }^{2}$. Importante frisar que este trabalho social se deu em meio a um ambiente de concorrências e lutas, destacando-se as ocupações de terra do Movimento dos Trabalhadores Rurais Sem Terra (MST), pressionado pela reforma agrária.

Parte-se da hipótese de que a Agroanalysis, ao longo daquela década, criou uma arena de debate entre representantes deste particular grupo de pressão do patronato rural para construir uma nova "imagem" e uma maior "unidade", tendo como referência explícita a considerada vitoriosa trajetória da Frente Ampla da Agropecuária Brasileira (FAAB), organizada para atuar na Constituinte de 1988 com objetivo de "aglutinar os interesses do setor agropecuário e influir na nova institucionalidade que se construía após o fim do regime militar, articuladamente, na elaboração da nova Constituição" (Gryinszpan, 2009: 9).

2 A Agroanalysis circulou em duas fases. A primeira durou de janeiro de 1977 a setembro de 1989. Na época, tinha distribuição gratuita e como patrocinadores o Banco Central, o Banco do Brasil e o extinto Banco Nacional de Crédito Cooperativo. Quando esse mecenato terminou, parou de circular. Esta pesquisa se dedica à fase que se inicia em 15 de setembro de 1994, quando volta a ser publicada, mas como "um investimento de risco", como explica seu editorial. Seus promotores esperavam obter boa aceitação para atrair publicidade que permitisse manter uma equipe de pesquisadores permanente voltada para 0 tema da economia agrícola, visando ter como patrocinadores o "complexo agroindustrial". 
A Associação Brasileira de Agribusiness (ABAG), fundada em 1991 e então presidida por Ney Bittencourt de Araújo, teve papel central na retomada da publicação da Agroanalysis pela FGV, suspensa em 1989³ É personagem central deste processo a figura de Roberto Rodrigues, Ministro da Agricultura do primeiro Governo Lula. Ele foi secretário da FAAB e por este papel, segundo Gryinzpan, teria ganhado projeção nacional, por ter se apresentado "como um contraponto às posições mais extremadas da UDR, além de se tornar um porta-voz reconhecido de uma agropecuária que se apresentava como moderna, que se pensava para além da fronteira da fazenda e se internacionalizava" (Ibid.: 9).

A análise da Agroanalysis ${ }^{4}$ se concentrou nos editoriais, entrevistas e artigos de lideranças do setor, assim como de seus colaboradores frequentes, quando o termo agribusiness ou agronegócio tiveram algum destaque. A palavra "agronegócio" vai sendo incorporada ao léxico da revista aos poucos, quase que ao mesmo tempo em que Rodrigues torna-se quase onipresente em suas páginas, pregando em artigos e entrevistas a necessidade de se criar uma "unidade" do setor para mudar sua "imagem" perante a sociedade.

As páginas da Agroanalysis acabam evidenciando como esse processo de ascensão do termo "agronegócio" faz parte de uma configuração que tem como polo oposto a luta pela reforma agrária enquanto política pública que vinha sendo implementada durante os anos 90. Isto porque seus artigos expressam como estes grupo de intelectuais e representantes deste setor ${ }^{5}$, refletidos e refratados pela revista, foram primeiramente confrontados por uma crise econômica, que se agrava simbolicamente pela ascensão da luta pela terra no Brasil, por meio das “invasões". É a partir do final dos anos 9o, que os colaboradores da revista, incentivados pelo grande aumento da lucratividade dos produtos agrícolas de

3 Segundo Grynszpan, (Anpocs, 2009), após sua morte em 1996, recebeu uma homenagem na forma do livro "Ney Bittencourt: o dínamo do agrobusiness" publicado com apoio da Sociedade Rural Brasileira (SRB), então presidida por seu velho amigo, o agrônomo e produtor rural Roberto Rodrigues.

4 Este levantamento se fez no âmbito da pesquisa "Sociedade e Economia do Agronegócio: um estudo exploratório", com apoio do CNPq, Faperj e da Fundação Ford e coordenada pelos pesquisadores Beatriz Heredia (UFRJ), Moacir Palmeira (MN/UFRJ) e Leonilde Medeiros e Sergio Pereira Leite do CPDA/ UFRRJ.

5 Em sua tese, que "investiga o agronegócio como fenômeno político", Ribeiro Neto (2018) usa o conceito de "concertação política do agronegócio" para tratar do que ele define como "composição intersetorial de caráter político entre representações da agricultura, de segmentos da indústria e de serviços conectados a ela que, alicerçada na categoria agribusiness/agronegócio, atua de forma multilateral, coordenada, institucionalizada e sistemática. Seu objetivo central é a ação voltada a convencer a opinião pública a valorizá-la e pressionar o Estado a inseri-la como elemento estratégico no planejamento governamental" (Ibid.:154). Os agentes que atuaram na revista Agroanálysis neste período, que transitaram com fluidez entre os campos empresarial, midiático, acadêmico e estatal, constituem parte fundamental desta concertação. 
exportação, passam a usar mais frequentemente o termo "agronegócio". Neste cenário de pujança econômica, o grupo que até então atuava na revista ascendeu a uma espécie de "palanque oficial", o Ministério da Agricultura, Pecuária e Abastecimento (MAPA), que passou a ser chefiado por seu porta-voz, Roberto Rodrigues, no qual puderam difundir esta noção para o conjunto da sociedade como palavra oficial e legítima.

Este artigo é inspirado na análise feita pelo então presidente da Sociedade Rural Brasileira $(\mathrm{SRB})^{6}$, Luís Hafers, à revista Agroanalysis, publicada como entrevista na edição em fevereiro de 1998. Nela, Hafers. considerava absolutamente necessário que reformulassem a "imagem antiga" que a cidade possuía deles:

Num sistema democrático, o juiz final de todas as ações é a opinião pública, que por sua vez pressiona o Legislativo, que pressiona o Executivo. No governo totalitário tínhamos um atalho que era conhecer o ministro. Isso hoje não funciona mais" (Agroanalysis, fevereiro, 1998:3).

Por esta razão, sugere:

Precisamos de todo um trabalho de convencimento da opinião pública. As nossas relações com a imprensa são ruins. A imprensa ainda acha que o fazendeiro e o médio agricultor são latifundiários reacionários" (Agroanalysis, fevereiro, 1998:3)

Hafers, que na presidência SRB abriu o diálogo da entidade com o Partido dos Trabalhadores (PT), arremata: "Nós agricultores terminamos o ano que passou com uma imagem menos ruim, e o MST com uma imagem menos benéfica" (Agroanalysis, fevereiro, 1998: 5). Este artigo tem como hipótese que foi por meio do termo "agronegócio" que este setor do patronato rural passou a construir uma nova imagem que se consagrou, repercutindo para a

6 Segundo Mendonça (2010), a Sociedade Rural Brasileira "constituiu-se, desde as origens, na mais expressiva agremiação de proprietários rurais do país, criada na década de 1910 para fazer frente à Sociedade Nacional de Agricultura e com ela disputou, até os anos 1980, a liderança de todos os segmentos". É uma entidade "de bases estritamente regionais, que organiza setores do patronato rural oriundos do estado de São Paulo", embora, como observa a autora, nunca tenha prescindido do termo «brasileira» em sua denominação.

7 Esta percepção sobre a imagem ruim do setor neste período também é corroborada pelo trabalho de Andrade Júnior (2016), que demonstra em sua periodização dos combates à queima da cana e a superexploração dos trabalhadores dos canaviais, os bóia-frias, em São Paulo, que no primeiro período de lutas, entre 1988 e 1994, o tradicional empresariado deste setor, do qual faz parte Roberto Rodrigues e vários membros da SRB, "se viu ameaçado" diante da aproximação de importantes e diferentes sujeitos políticos, formando uma rede de aliados que segue enfrentando este empresariado por mais de 20 anos (Ibid.:45). 
sociedade brasileira uma ideia que associa essa palavra à modernização, eficiência econômica, competitividade, domínio tecnológico e produtividade, presumidos como sendo característicos desta particular formação econômica do meio rural brasileiro.

A Agroanalysis é um lugar privilegiado para se verificar este processo, pelo qual o termo "agronegócio" passou a ter publicidade e a se consagrar para se referir a um determinado conjunto de fenômenos associados à produção agropecuária nacional, porque a revista reuniu em suas páginas artigos, pesquisas e entrevistas com pesquisadores e lideranças de todas as principais associações patronais do setor agropecuário, como a SRB, Confederação Nacional da Agricultura (CNA), ABAG e Organização das Cooperativas do Brasil (OCB) ${ }^{8}$. É importante frisar, no entanto, que este discurso se construiu em torno de uma determinada configuração política em que a formação do conceito emergente sobre o "agronegócio" estabeleceu um diálogo com um adversário muitas vezes explícito, como na fala de Hafers, ou outras vezes oculto: o MST e a luta pela reforma agrária9.

\section{Revista Agroanalyis e a construção da hegemonia do "agronegócio"}

Em 1990, o então presidente da Agroceres, Ney Bittencourt de Araújo, publicou o livro "Complexo Agroindustrial: o Agribusiness Brasileiro" assinado por ele e dois técnicos da área, Ivan Wedekin e Luiz Antonio Pinazza, introduzindo o termo "agribusiness" no país. A criação do termo agribusiness deve-se ao

8 Uma revista com carimbo de uma instituição reconhecida pela comunidade acadêmica, como a FGV, não tem seu impacto medido pela sua tiragem, que é reduzida, cerca de 4.500 exemplares segundo seu "mídia kit" usado para vender publicidade (consultado na internet dia 9 de março de 2016). Também não é uma revista científica, cujos artigos podem ser analisados a partir do número de citações. Ela dá suporte técnico por meiode estudos sobre, por exemplo, oscilação de mercado e suas tendências e os impactos de medidas regulatórias. É considerada uma das referências mais conhecidas do setor, junto com o periódico "Conjuntura Econômica", segundo. Alfredo Wagner Berno de Almeida, que a cita no artigo "Agroestratégias e desterritorialização: direitos territoriais e étnicos na mira dos estrategistas do agronegócio", de 2010.

9 Este artigo não trata a agricultura familiar enquanto noção, nem como categoria oponente ao termo "agronegócio", tema já objeto de outros trabalhos como os artigos de Valente (2008) e Sauer (2008) que se concentram na crítica ou na justificação da dicotomia que então se estabelecia entre estes termos. A meu ver, o polo oposto ao termo "agronegócio" é a luta pela reforma agrária, não importa se ela se expresse na luta por reconhecimento de territórios tradicionais, como os dos indígenas e quilombolas, ou pelo parcelamento de latifúndios. Entrevista concedida pelo Superintendente Técnico da CNA, Ricardo Cotta Ferrreira (29/07/2008) contribuiu para esta pressuposição. Ao ser perguntado sobre qual era o "gargalo" do agronegócio, respondeu que o principal problema que o setor enfrentava era "a relativização do direito de propriedade no Brasil”, inibido em sua expansão não pela "reforma agrária” e sim por áreas quilombolas, indígenas e unidades de conservação. 
trabalho de dois professores da Universidade de Harvard, John Herbert Davis e Ray Allan Goldberg, autores do livro "A concept of agribusiness", publicado em 1957. Em 1994, como presidente da ABAG, Araújo intercedeu para que a FGV retomasse a publicação da revista Agroanalysis, criada em 1977 e suspensa em $1989^{10}$. A revista continua sendo publicada, mas agora pela GV Agro, centro de estudos do agronegócio da Escola de Economia da FGV de São Paulo, dirigido por Roberto Rodrigues, considerado por Luiz Antonio Pinazza, coautor do livro de Araújo e editor-executivo da Agroanalysis, "o grande mecenas da revista"

Por meio dos indícios que a análise do material desta revista deixaram entrever, pode-se afirmar, seguindo a trilha da reflexão de Grynszpan (2009), que a Agroanalysis tornou-se, na década enfocada por este artigo, uma das principais arenas em que determinados agentes se aglutinaram e se identificaram entre si, organizando-se em torno do trabalho de imposição deste novo termo que, ao mesmo tempo, estimulou que eles se constituíssem e se definissem enquanto grupo (Ibid.: 11). Essa hipótese é reforçada pelo fato de que, quando se tornou Ministro da Agricultura, Rodrigues levou consigo alguns de seus mais próximos colaboradores na revista para compor seu gabinete, como foi o caso de Regis Alimandro, redator-chefe da mesma de 1994 até o início de 2003.

Para Claus Offe, este processo de composição de poder associado a um grupo economicamente forte é normalizado em uma sociedade capitalista, na qual "o Estado depende do florescimento do processo de acumulação". Ou seja, mesmo antes que os setores do capital comecem a pressionar o governo com reivindicações políticas, "o capital goza de uma posição de controle indireto sobre os assuntos públicos” (Offe, 1984: 79). Em suma, sempre está em uma posição de poder frente a determinadas forças políticas, sejam elas suas representantes ou não. Este autor observa que a atitude "extremamente solícita" relativa "aos interesses empresariais, que todo Governo do Estado capitalista é estruturalmente forçado a assumir, reduz os esforços dos capitalistas de 'bater as portas"'. É por esta razão, que as comunicações entre as associações empresariais e o Estado, comparadas às dos sindicatos e movimentos sociais, são publicamente bem menos visíveis. Há menos necessidade de mobilizar o apoio de aliados

10 O editorial da edição de 15 de fevereiro de 1996, que homenageia Ney Bittencourt, falecido em 14 de janeiro desse mesmo ano (p. 15), elucida o contexto do ressurgimento da Agroanalysis. Nele, o editorial da revista conta que Araújo, então presidente da Agroceres, havia aparecido na FGV em 1994, "capitaneando um seleto grupo de empresários do agribusiness". Segundo o editorial, "uma parcela expressiva do PIB estava representada no prédio da Praia do Botafogo" e a visita tinha o "único objetivo" de mostrar ao então diretor do IBRE, Dr. Julian Chacel, a necessidade de a FGV relançar a revista Agroanalysis. Entrevista concedida por telefone em 17 de novembro de 2011. 
externos, são relações consideradas mais técnicas e estes interesses são vistos como falando em nome do país, o que, do ponto de vista do capital e do Estado capitalista, significa maior acumulação, ou seja, um maior Produto Interno Bruto (PIB) (Ibid.: 80).

Dez anos após o relançamento da revista Agroanalysis, em outubro de 2004, foi publicado o resultado de uma sondagem para detectar o nível de satisfação de seus leitores, no qual seus editores apresentam seu desempenho e expressam esta posição:

Há três décadas, a Agroanalysis mantém seu foco de atenção voltado para o campo, apontando oportunidades, obstáculos e, principalmente, as necessidades e preocupações do empreendedor rural. Fazemos parte deste cenário, e muito nos orgulha sermos um agente da potência mundial que se tornou o agronegócio brasileiro" (Agronalysis, outubro, 2004: 7).

Segundo seu editorial, o resultado da sondagem ${ }^{12}$ iria nortear sua linha editorial e "mais importante do que ser uma 'bússola' para nossa Redação", seu conteúdo iria pavimentar "um caminho ainda mais direto rumo ao sucesso empresarial do agronegócio". Acrescenta ainda que, por ter sempre se pautado "pela base científica e acadêmica de seu conteúdo e pelo gerenciamento profissional", estava se tornando "ainda mais potente" com estes resultados ${ }^{13}$ (Agroanalysis, outubro, 2004: 7).

Como veremos a seguir, o caminho que a Agroanalysis percorre para se tornar parte do "cenário" do agronegócio brasileiro atravessa um diálogo permanente com representantes dos setores dominantes do meio rural, bem como intelectuais, cuja produção científica e jornalística tem papel determinante na própria estruturação deste contexto e na construção de significados atribuídos ao termo agronegócio que, assim como qualquer categoria, possui um caráter instrumental e pode servir de testemunho de certas particularidades

12 Embora, não divulgasse o total dos entrevistados, apresenta dados positivos sobre sua receptividade: $46 \%$ dos leitores liam quase toda a revista, $25 \%$ só as partes em que tinham interesse, $19,8 \%$ passavam para outras pessoas lerem e 16,5\% liam mais da metade. Além disso, 87\% dos leitores tinham muito interesse na revista, $52 \%$ davam "ótimo" e $40 \%$ davam "bom" em termos de credibilidade e $92 \%$ tinham opinião positiva. Segundo Mídia-Kit 2015/2016 da revista, 29\% de seus leitores são produtores rurais, $16 \%$ são profissionais de empresa pública, $13 \%$ professores, $10 \%$ profissionais de empresa agrícola, $8 \%$ profissional do setor de máquinas e insumos, $8 \%$ consultores independentes, $5 \%$ profissionais do setor financeiro, $4 \%$ profissionais de cooperativas, $3 \%$ estudantes, 3\% outros. Disponível em: <http://abisolo. com.br/files/MidiaKit-Revista-AgroAnalysis.pdf>. Acesso em: 23 mar. 2020.

13 A pesquisa foi encomendada pela FGV Consult à Demanda Pesquisa e Desenvolvimento de Marketing. Seus questionários foram respondidos por e-mail e por meio de resposta paga encartada na revista (Agroanalysis, Outubro, 2004: 7). 
estruturais de uma sociedade dada (Elias, 2006). A princípio, em um momento de crise por conta dos efeitos do Plano Real, o termo utilizado pela revista para dar nome a uma suposta nova realidade do meio rural brasileiro, então em processo de transformação, era "agribusiness", oriundo do idioma inglês. Quando este novo contexto economicamente bem-sucedido para o setor agropecuário se consolida, a palavra abrasileirada, "agronegócio", passa a ser mais adotada e, em novembro de 1999, vai parar na linha fina da capa, abaixo do nome da revista, substituindo o slogan "A revista de economia agrícola da FGV" para "A revista do agronegócio da FGV"14.

Ao longo dos dez anos de edição analisados, a revista foi passando por uma crescente sofisticação editorial. São várias as modificações em seu projeto gráfico, tornando-se uma publicação visualmente mais bonita. A primeira delas ocorre na edição de novembro de 1997, quando ela, como nos anos anteriores, apresenta as 100 maiores empresas do agribusiness, encabeçada neste ranking, naquele ano, pela Cervejaria Brahma. Nesta edição, a Agroanalysis aparece dotada de mais recursos, por trazer inovações gráficas, ou seja, mais cor em suas páginas e uso de fotos. Outra grande mudança do projeto gráfico ocorre em junho de 1999, quando a apresentação de seu editorial e de seu índice, que dividem duas páginas, se torna visualmente mais expressiva. Em abril de 2000, o projeto da revista novamente se altera e, na edição de novembro daquele ano, o editorial passa a circular com o nome "O agronegócio é o seguinte", permanecendo assim até o fim do período analisado. Após a edição de Maio/Junho de 2001, a revista que antes saía com capa do dia 15, passa a circular após o dia 5 de cada mês. Em maio de 2003 modifica-se sua equipe até então chefiada por Regis Alimandro, que sai da Agroanalysis para assessorar Roberto Rodrigues no MAPA, que leva também Ivan Wedekin, colaborador frequente da revista. Em janeiro de 2004, já com nova equipe no comando, ocorre outra mudança na revista, que fica mais arrojada graficamente.

Neste período, as edições da Agroanalysis passam a contar com número expressivo de patrocinadores e peças publicitárias sofisticadas graficamente, a ponto de, a partir de 2004, a entrevista mensal, publicada na seção chamada de "Abre Aspas", começar a ser publicada não na página 3, mas sim na página 4, indicando interesse do setor comercial da revista em deixar as páginas 2 e 3 livres para publicidade. Embora esta verba no Brasil seja altamente concentrada em pouquíssimas publicações ${ }^{15}$, a carta de anunciantes da Agroa-

14 Isto ocorre na edição de 15 de novembro de 1999, mas não há nenhuma explicação no editorial sobre essa mudança.

15 Disponível

em:

$<$ http://observatoriodaimprensa.com.br/interesse-publico/_ed772_falta_ diversidade_e_sobra_concentracao_na_midia_brasileira/>. <http://baraodeitarare.org.br/index.php? 
nalysis passou a contar com empresas "pesos-pesados" da área como a Bayer, Monsanto, Cargil e Bunge.

Na década analisada, as edições da Agroanalysis se caracterizaram pela eleição de um tema principal como, por exemplo, a fruticultura ou a pecuária, a soja ou o crescimento da produção agrícola do Mato Grosso, de Goiás, cada qual trazendo uma série de artigos de especialistas, não necessariamente colaboradores fixos. Também foram publicadas pesquisas abordando várias temáticas, como a "agricultura familiar" (Agroanalys, setembro, 2000: 31-40). Eram temas recorrentes, o preço das terras e a ocupação da mão-de-obra agrícola. Há também uma particular atenção às negociações internacionais, foco de artigos de vários colaboradores, que geralmente traziam críticas ao protecionismo e aos subsídios agrícolas dos Estados Unidos e da União Europeia. Embora desse espaço para as justificativas apresentadas para essas políticas, como a multifuncionalidada e a questão social e cultural vinculada à manutenção de seus agricultores, a revista se coloca como franca porta-voz do livre-comércio.

Duas questões polêmicas aparecem ao longo destes anos: os transgênicos e a reforma agrária. No caso do primeiro, a mudança é emblemática. A edição especial de agosto de 1999 abre espaço igualitário para "cientistas, pesquisadores, políticos, ambientalistas e homens de negócio", segundo seu editorial. Ao contrário das 60 páginas usuais, esta edição teve 98 para comportar todos os articulistas convidados, como a então senadora do PT, Marina da Silva (p. 64-65) e o ex-ministro da Ciência e Tecnologia, Bresser Pereira (p. 3-4) (Agroanalysis, agosto, 1999). Ao longo do tempo, no entanto, a revista assume a defesa de sua liberação, publicando apenas artigos favoráveis ao cultivo e à comercialização de transgênicos.

No caso da reforma agrária, a Agroanalysis demonstra inicialmente uma postura ponderada e até favorável, embora acentue a importância de que ela fosse acompanhada por uma visão do mercado, ou melhor, do "agribusiness". Importante observar que é, na segunda metade da década de 90, após a aprovação da Lei Agrária que regulamenta a desapropriação de terras, que o número de ocupações cresce de maneira exponencial no Brasil, tendo o seu auge no ano de 1999 (Gráfico 1). Com a desvalorização do real em janeiro de 1999 e a Medida Provisória n. 2.027-38, de maio de $2000^{16}$, que impede a desapropriação e vis-

option=com_content\&view=article\&id=611:governo-federal-patrocina-concentracao-da-midia-nobrasil\&catid=12\&Itemid=185>. Acesso em: 25 abr. 2016.

16 Esta MP foi substituída em agosto de 2001 pela MP 2.183-56, que além de determinar que "o imóvel rural objeto de invasão motivada por conflito agrário não será vistoriado, avaliado ou desapropriado nos dois anos seguintes à sua desocupação", ainda exclui do Programa de Reforma Agrária do Governo Federal 
toria de propriedades rurais ocupadas por movimentos sociais, o crescimento começa a se inverter.

\section{GRÁFICO 1 - BRASIL - NÚMERO DE OCUPAÇÖES - 1988-2012}

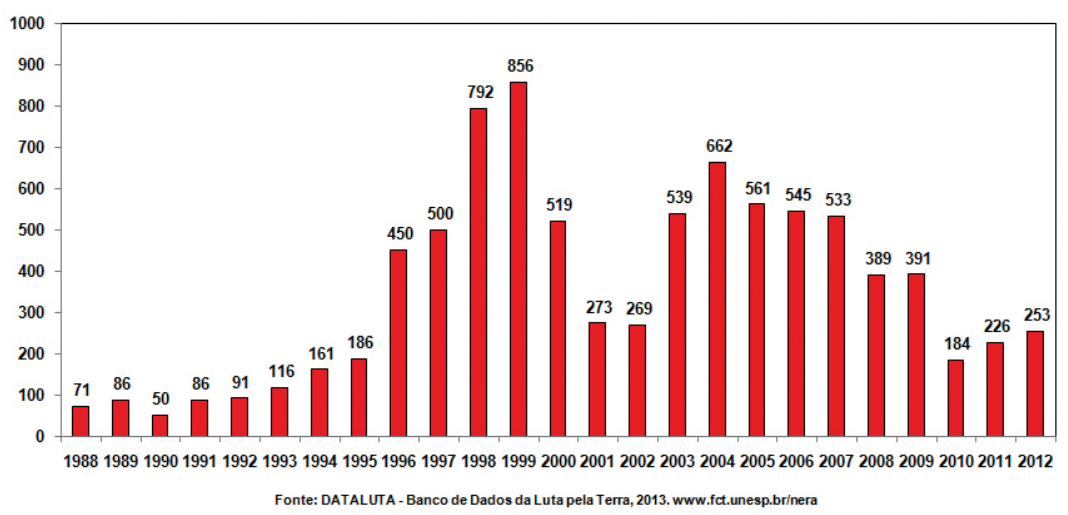

Ao acompanhar, de um lado, o aumento das invasões/ocupações de terra e, de outro, a crescente pujança econômica da agricultura voltada para exportação, a revista passa a dar mais espaço para opiniões desqualificadoras e críticas ao modo como vinha sendo feita a reforma agrária, visto que, por exemplo, não haveria, a seu ver, informações sobre o resultado econômico dos assentamentos. Embora sempre tenha dado espaço para opiniões contrárias às "invasões" de terra e às ameaças ao direito de propriedade, nos anos 90 a revista manteve a postura de nunca se colocar frontalmente contra a reforma agrária, apresentando geralmente a defesa de soluções para essa questão baseadas no "mercado".

O artigo que marca esta posição inicial é a primeira colaboração de Luiz Antonio Pinazza, que assim como Araújo e Wedekin foi um dos autores do livro que trouxe o termo agribusiness para o Brasil ${ }^{17}$. Seu primeiro artigo, ainda como gerente de negócios da Agroceres, tem por título, "Os novos paradigmas para a reforma agrária” (Agroanalysis, fevereiro, 1996:20-21). Nele, o autor enfatiza que não a considerava uma questão do passado e atribui o problema à "conservadora" Lei de Terras de 1850, fazendo uma comparação com o "caminho bem diferente trilhado pelos EUA" em relação a esta questão na mesma época, por meio do Homestad Act. Neste ano, a luta do MST vinha ganhando grande destaque na mídia nacional (Comparato, 2000) graças à visibilidade conquistada pelas

"quem for identificado como participante direto ou indireto em conflito fundiário que se caracterize por invasão de imóvel rural". Disponível em: <http://www.comciencia.br/reportagens/agraria/agro4.shtml >. Acesso em: 23 mar. 2020.

17 Após este artigo, Pinazza volta frequentemente a colaborar com a Agroanalysis, passando a ser incorporado aos quadros fixos da revista em abril de 1998 e tornando-se editor-executivo em dezembro de 2003. 
ocupações de terra no Pontal do Paranapanema, em São Paulo, tendo os sem-terra se tornado até personagens de uma "novela das 8", da TV Globo, a novela "Rei do Gado"18. Neste contexto, Pinazza tem uma postura favorável. Alerta para as ameaças que pairam sobre os minifúndios e as pequenas propriedades, critica o fato de só terem sido assentadas 131,7 mil famílias de 1986 a 1994 e afirma que êxodo rural só fez inchar as cidades.

No artigo, Pinazza usa o termo agribusiness, quando, por exemplo, menciona que naquele contexto "não se podem esquecer alguns aspectos do agribusiness globalizante em curso" e quando diz que o Brasil já contava com "um agribusiness consolidado". Seu argumento é que, como sua estruturação não tinha sido homogênea no país, era "imprescindível priorizar as regiões onde prevalece a agricultura tradicional, de baixa agregação de valor e incipiente tecnificação". Também opinava que os municípios tinham que eleger os produtos nos quais tinham vantagens comparativas para serem produzidos com "qualidade total", inclusive nas atividades pós-porteira, para atender o mercado local, regional, estadual, nacional e internacional. Para ele, a política agrária e agrícola sob o "enfoque sistêmico do agribusiness (..) leva em conta aspectos do mercado" que não podem ser desconsiderados ao se pensar abastecimento e implementação de programas de segurança alimentar (Agroanalysis, fevereiro, 1996: 20-21).

Este artigo demonstra que, em meados da década de 90, a revista tinha uma posição favorável à reforma agrária. Com enfoque no mercado, suas análises não condenavam a política de assentamentos do governo. Em artigos posteriores, como o do especialista em direito agrário Luiz Augusto Germani, publicados a partir de 2003, a posição passa a ser contra desapropriações e contra a lei de confisco de terras onde se encontrasse trabalho escravo. Um deles fornece orientações aos "proprietários rurais" de "instrumentos legais para se proteger das invasões" como o "interdito proibitório" (Agroanalysis, setembro, 2003:1214). Também repetindo um discurso bastante usual na época, Germani "festeja o instrumento de compra de terra, que viria a ser adotado pelo governo" por estar, segundo ele, adequado à realidade do país, na qual era "cada vez mais difícil

18 Pesquisa encomendada pela Confederação Nacional da Indústria (CNI) ao Ibope, feita entre 6 e 10 de março de 1997, que entrevistou mais de 2000 pessoas em todas as capitais do país encontrou na época um dado surpreendente: $94 \%$ das pessoas concordavam que o Movimento Sem Terra devia lutar por reforma agrária e $88 \%$ concordava que o governo deveria confiscar todas as terras improdutivas e distribuí-las aos sem-terra. Além disso, $77 \%$ dos entrevistados achavam invasão de terra "um instrumento de luta importante, desde que não haja violência e morte". Os dados dessa pesquisa foram publicados no Jornal dos Trabalhadores Rurais Sem Terra, na edição de abril/maio de 1997 (:14) e divulgados amplamente pela mídia a ponto de serem referenciados em uma cronologia publicada na revista Veja. Disponível em: $<$ http://veja.abril.com.br/idade/exclusivo/reforma_agraria/cronologia.html>. Acesso em: 23 mar. 2020. 
encontrar imóvel rural improdutivo para fazer assentamentos"19 (Agroanalysis, agosto, 2004: 48).

\section{Crise agrícola e mudança de imagem}

As primeiras edições da Agroanalysis revelam que o termo "agronegócio" praticamente não é usado tanto em suas entrevistas, como nos artigos principais ou mesmo no editorial. O termo mais usado é "agribusiness" e mesmo este, com muita parcimônia. A primeira vez que o termo "agronegócio" aparece é na sessão "Janela Aberta”, da terceira edição, de novembro de 1994, espaço concedido para pesquisadores, profissionais e lideranças do setor. $\mathrm{O}$ artigo tinha como título "Compromisso com o agribusiness e com o futuro" e era de autoria de um engenheiro agrônomo, então "diretor de agribusiness" do Banco Bamerindus, Laércio Yamauti. Nele, o autor explica a importância que o sistema financeiro privado dava para o agribusiness e esclarece o próprio conceito, gestado nos EUA nos anos 50. "O chamado complexo agroindustrial, na verdade, integra mais do que a cadeia de atividades agropecuárias e industriais, posto que também compreende outras atividades, tais como as de natureza financeira, o comércio e os transportes" (Agroanalysis, novembro, 1994: 48). No artigo, o termo "agronegócio" aparece uma vez. Ou seja, o autor oscila entre o uso dos termos "agronegócio" ou "agribusiness", característica que vem a se repetir em várias edições subsequentes da Agroanalysis até que o termo agronegócio passa a ganhar maior destaque e a ilustrar de modo fixo, tanto a capa quando o editorial da revista.

Em janeiro de 1995, início do governo de Fernando Henrique Cardoso (FHC), a revista traz a entrevista de Guilherme Leite da Silva Dias, da FEA/USP e diretor presidente da Fipe (Fundação Instituto de Pesquisa Econômicas), encarregado de elaborar propostas preliminares para a política agrícola da nova gestão. O editorial critica a mudança na política de crédito, ocorrida em meio ao plantio e à colheita, e se encerra com o seguinte parágrafo:

$\mathrm{O}$ agribusiness espera que um ministro forte na pasta da Agricultura possa conter e fazer reverter qualquer forma de discriminação setorial e de inconsistência nas políticas adotadas. É preciso que a agricultura fique liberada para se financiar no mercado financeiro normal (Agroanalysis, janeiro, 1995: 7).

19 Segundo Delgado (2010), baseando-se no Sistema Nacional de Cadastro Rural, há 120,4 milhões de hectares de terras no Brasil declaradas como improdutivas e 172,95 milhões de terras devolutas, ou seja, públicas não legalizadas. Ou seja, $34 \%$ do território nacional poderia ser objeto de uma reforma agrária. 
Ou seja, a revista se coloca como porta-voz do setor e usa o termo "agribusiness" como sinônimo de agropecuária. Na edição de maio de 1995, o editorial novamente se expressa como porta-voz do setor agrícola ao descrever a crise que começa a se anunciar. Aborda a safra recorde de grãos que se tornou um "alento" para o sucesso do Plano Real e "um pesadelo para os produtores", sem a necessária liquidez de crédito para irrigar seus negócios e que, com a comercialização da safra, assistiam aos preços despencarem de forma desenfreada. Informa que a queda de preços estava sendo incrementada pela importação de grãos: o milho chegou a ser negociado a $\mathrm{R} \$ 4,00$ a saca em Santa Catarina e o arroz a R\$ 6,00 a saca no Rio Grande do Sul (Agroanalysis, maio, 1995: 7).

A capa da edição de junho de 1995 anuncia uma entrevista com Roberto Rodrigues, então presidente da SRB (Sociedade Rural Brasileira), com o título "Reformas estruturais para a agricultura". Nela, ele propõe uma "redefinição do papel do Estado", mas não sua ausência, visto que este tem que garantir o abastecimento, mas propõe "a organização dos agricultores divididos, dispersos e desunidos na vastidão e na diversidade regional, tecnológica, étnica, cultural e edafoclimática do Brasil" (Agroanalysis, junho, 1995:1-2). Sua análise da situação da agricultura, classificada como "lúcida" pelos editores, não menciona "agronegócio" nem "agribusiness".

O editorial desta mesma edição (Agroanalysis, junho, 1995: 7) se dedica à "delicada" situação pela qual passava a agricultura. Menciona que, como os membros da "bancada ruralista" ameaçaram não votar nos projetos do governo, se este não resolvesse a questão do endividamento, acabaram dando espaço para que "setores da mídia", mais precisamente a revista Veja, publicasse a matéria de capa "Os reis do calote rural" ${ }^{20}$, em sua edição semanal, em que foi apresentada uma lista de produtores rurais endividados com o Banco do Brasil há vários anos. Segundo o editorial, essa matéria da Veja falava mais da "exceção e "pouco" do rotineiro" e era fruto do fato de que os "grandes veículos de comunicação" eram "essencialmente urbanos", portanto, costumavam "refletir os supostos interesses da população da metrópole". O editorial defende que a maioria dos "empresários rurais" que tem acesso ao sistema de crédito não correspondia àquele descrito pela revista. Explica que o contexto atual agravou um problema já antigo, que era a dívida da agricultura originária do Plano Collor, e se coloca contra a posição da bancada ruralista de bloquear as votações do Congresso Nacional, por que o benefício financeiro a curto prazo impediria as

20 Edição 1392, 17 de maio de 1995, Manchete completa: "Os reis do calote rural: milionários, - eles tomam dinheiro público e nunca pagam - quem são e como vivem” pp. 30-37. 
reformas tributária e fiscal que iriam de fato desonerar a produção e melhorar a competitividade da agricultura.

Este editorial é interessante porque é a primeira vez que a revista manifesta a preocupação com a "imagem pública dos produtores rurais" que, assim como a fala de Hafers, de três anos depois, passa a se repetir em suas páginas e está associada ao processo de consolidação do termo agronegócio, conceito que passa a exprimir uma nova imagem, uma nova representação deste setor rural.

Pouco depois, na edição de agosto de 1995, tanto o editorial, como um artigo analisaram a falta de conquistas da Marcha à Brasília apelidada pela imprensa de "Caminhonaço". A mobilização foi realizada no mês de julho por agricultores endividados, que não receberam nada do governo. Para o editorial, o fato positivo da mobilização foi a "mensagem nítida", anunciada "com toda a clareza": o setor agrícola deveria "buscar as soluções de mercado para suas necessidades de financiamento". Além disso, a "marcha" tinha demonstrado que a agricultura brasileira não era subsidiada e vinha pagando já há algum tempo juros reais positivos e elevados. Assumindo a postura de porta-voz, o editorial diz esperar que "o governo não discrimine o setor e não atrapalhe..., viabilizando uma relação madura entre o mercado financeiro e a agricultura" (Agroanalysis, agosto, 1995: 7).

É interessante recordar que justamente na semana seguinte ao "Caminhonaço”, o MST realizou seu $3^{\circ}$ Congresso Nacional. Ao contrário dos representantes dos produtores rurais, suas lideranças foram recebidas pelo presidente FHC, no dia 27 de julho de 1995. Com este gesto, o então presidente reconheceu o MST como legítimo interlocutor perante o governo federal, o que despertou grande interesse por parte de repórteres e grandes veículos de comunicação que passaram a cobrir com mais intensidade suas lutas. Esta atenção se intensificou ainda mais após o despejo violento de sem terras ocorrido na Fazenda Santa Elina, em Rondônia, no mês seguinte, quando foram mortos 11 trabalhadores rurais, entre eles uma menina de 7 anos, que levou um tiro nas costas quando fugia.

Os artigos que abordam o tema reforma agrária, assim, como a crise agrícola, demonstram que a revista refletiu e refratou o ambiente político que a circundava, procurando construir representações sobre as transformações que passaram a ocorrer no meio rural brasileiro diante da estabilização monetária e do governo de FHC, procurando legitimar-se como um palco da rearticulação de atores oriundos de grupos dominantes envolvidos nas questões vinculadas à produção agropecuária brasileira. Esta passa por uma profunda crise e depois se recupera economicamente a partir de 1999. Artigo de Carlos José Caetano Bacha, publicado pela Agroanalysis em junho de 2004 (p. 23), traz dados que 
sintetizam bem esta transformação. Segundo ele, "na década de 1990, foram concedidos créditos rurais equivalentes a $1 / 3$ do montante concedido na década de 1970". Além disso, a política de preços mínimos foi alterada significativamente na segunda metade da década de 90: os empréstimos do Governo Federal (EGFs) praticamente se extinguiram a partir de 1999, e as Aquisições do Governo Federal (AGFs) tiveram forte redução. Além da escassez de recursos públicos, foi extinta a Empresa Brasileira de Extensão Rural (Embrater) pelo Governo Collor, e as atividades públicas de pesquisa sofreram com a escassez de recursos. Este contexto levou à falência ou trocas de mãos de várias empresas do complexo agropecuário.

Por outro lado, é nesse período que as lutas por terra e reforma agrária, protagonizadas pelo MST, ganham muita visibilidade na cena pública brasileira. Importante destacar que é em junho de 1996, dois meses depois assassinato de 19 sem terras do MST, em Eldorado do Carajás (PA) que é instituído o PRONAF ${ }^{21}$ (Programa Nacional de Fortalecimento da Agricultura Familiar). Em 1997, um ano após o "Massacre de Eldorado do Carajás", o MST protagoniza uma marcha que recebe grande atenção midiática: três "colunas" de sem terras do MST, vindos de São Paulo (SP), Rondonópolis (MT) e Governador Valadares (MG) chegam à Brasília depois de dois meses de caminhada, acompanhadas por cerca de 100 mil pessoas e são recebidos por todas as autoridades instituídas dos três poderes, inclusive o Presidente FHC. Naquela semana também foi lançada uma exposição de fotos de Sebastião Salgado ${ }^{22}$ retratando os sem terras do MST, reunidas também em um livro, com textos de José Saramago e vendido com um CD de músicas de Chico Buarque dedicadas à luta pela terra, que contribuiu para divulgar o MST nacional e internacionalmente.

Neste contexto de crise agrícola e da emergência de conquistas voltadas para os movimentos sociais do campo, a revista expressa a articulação de formas de reação do setor. A primeira medida explícita foi a implementação, por meio de

21 Decreto ${ }^{\circ}$ 1946, de 28 de junho de 1996. Antes do Pronaf, o Governo Itamar Franco criou o Programa de Valorização da Pequena Produção (PROVAP), atendendo às demandas dos movimentos sociais do campo (MST, Contag (Confederação Nacional de Trabalhadores na Agricultura), DNTR/CUT (Departamento Nacional de Trabalhadores Rurais da CUT), Movimento de Mulheres Agricultoras, Movimento dos Atingidos por Barragens, Conselho Nacional de Seringueiros, Movimento Nacional dos Pescadores) que se mobilizaram conjuntamente no "Grito da Terra" ocorrido nos dias 9 e 13 de maio de 1994. Em 1995, houve o II Grito da Terra reunindo novamente diversos movimentos sociais do campo exigindo, entre outras pautas, crédito diferenciado para a pequena produção familiar.

22 Sebastião Salgado estava no Brasil para fazer fotografias dos sem-terra para sua exposição "Exodus", viajando imediatamente para o local do massacre de Eldorado do Carajás logo que teve notícia. Foi sua a iniciativa de fazer as exposições itinerantes, editar o livro e convidar Chico Buarque e José Saramago. A renda da exposição e do livro, acompanhado do CD, foi revertida para o MST. 
um decreto do ministro da Agricultura, por "inspiração" do Presidente FHC, do Fórum Nacional da Agricultura (FNA), que dura de setembro de 1996 até outubro 1997 e que recebe destaque na Agroanalysis. O editorial de junho de 1997 explica a iniciativa, cujo objetivo "a partir da visão sistêmica do agronegócio" era "formular soluções de política agrícola através da articulação entre governo e iniciativa privada", inaugurando "um novo tipo de diálogo com o setor" (Agroanalys, junho, 1997:6). O FNA era organizado em 36 grupos temáticos específicos (Agroanalysis, julho, 1997:19), que iam de cadeias de agronegócios a aspectos da política agrícola como, por exemplo, comercialização, educação e tributos. Muitos deles, em reuniões prévias, já haviam produzido documentos consensualmente que, em julho, seriam discutidos em grupos regionais compostos por lideranças locais. Em fins de outubro, o FNA deveria encaminhar suas conclusões ao presidente FHC. Ou seja, o Fórum constituiu-se como etapa de articulação política que favoreceu o debate e a construção de uma agenda comum, recebendo grande espaço na Agroanalysis. É depois da experiência do Fórum, em 1997, que o termo agronegócio passa a aparecer com mais regularidade em suas páginas, sendo inclusive mencionado na entrevista dada pelo presidente FHC nesta ocasião (Agroanalysis, outubro, 1997:1-3). Este processo de articulação evidenciado na revista culmina na realização do $1^{\circ}$ Congresso da ABAG, em junho de 2002.

\section{A ascensão da nova "Frente Ampla da Agropecuária Brasileira"}

Roberto Rodrigues, ministro da Agricultura do primeiro governo de Luis Inácio Lula da Silva, estreia nas páginas da Agroanalysis em uma entrevista publicada em junho de 1995. Ex-presidente da OCB, de 1985 a 1991, secretário-geral da Frente Ampla da Agropecuária Brasileira (FAAB) entre 1986 e 1988, presidente da SRB, de 19941996 , e fundador da $A B A G^{23}$, passa ao longo dos anos a ser praticamente onipresente nas edições desta revista até assumir a pasta da agricultura da primeira gestão do PT na Presidência da República. Depois da entrevista de 1995, Rodrigues passa a ser presença frequente nas edições da revista durante os anos 1996 e 1997 até assumir uma coluna fixa, a "Diário de Bordo", cuja nova titularidade é anunciada na capa da edição e saudada no editorial.

23 Gameiro demonstra a estreita vinculação de Rodrigues como setor sucroalcooleiro. Plantador de cana-de-açúcar, foi um importante mediador da violenta greve de Guariba (1984), município onde tem fazenda, provocada por mudanças no corte de cana. Foi ele que persuadiu os usineiros a voltarem atrás (Gameiro, 2017: 113). Embora tenha tido um papel-chave na defesa da agroenergia quando foi ministro não se apresenta como porta-voz deste setor em sua participação na revista Agroanalysis durante o período analisado 
Sua última coluna, com o título "A torcida", é publicado em janeiro de 2003, quando o editorial Agroanalysis anuncia "com muita alegria e forte expectativa" sua nomeação para o Ministério da Agricultura, desejando-lhe: "saúde e sorte, amigo" (Agroanalysis, janeiro, 2003: 7). No mês seguinte, fevereiro de 2003, a revista traz na capa uma pequena foto de Rodrigues e a chamada "Revolucionário: um agricultor no Ministério da Agricultura”. A entrevista da edição é com o próprio e tem como chamada: "O PCCA chega ao poder" (p. 3-7), nome que ele dá ao partido que ele representa: "Partido do Campo, do Cooperativismo e do Agronegócio", visto que não era filiado a nenhum partido tradicional, o que podia enfraquecer sua posição dentro do governo.

De sua primeira entrevista até sua nomeação como Ministro, podemos considerar a trajetória de Rodrigues como tendo um paralelo com o interesse sempre explícito na Agroanalysis de transformar a imagem do produtor rural perante a opinião pública urbana, processo associado à consagração pública do termo agronegócio e de seus porta-vozes até então reunidos em torno da revista. Importante recordar que esse percurso se dá ao longo de um período que se inicia com intensa fragilização do setor, derivada da redução drástica dos instrumentos públicos de apoio à agropecuária e seguida por uma forte e rápida recuperação, processo explícito nas páginas da Agroanalysis na década analisada. A partir de 1999, a crise dá lugar a uma recuperação econômica expressiva, diante da desvalorização cambial e do aumento do preço das commodities agrícolas, a ponto de a participação do setor agropecuário no PIB ter aumentado $67 \%$ desde 1994, chegando a 9,7 \% do PIB em 2003. Esses dados reverteram a tendência de queda de participação do setor agropecuário verificada desde 1947 até 1993, quando em relação ao PIB nacional a participação do setor caiu de 20,7\% do PIB para 5,8\%. (Bacha, Agroanalysis, junho, 2004: 2324).

É na medida em que o setor agropecuário e agroindustrial se torna bem-sucedido e aumenta sua participação nas exportações, que o termo "agronegócio" passa a ser adotado cada vez mais para se referir a esse fenômeno ${ }^{25}$. Se, nas edições iniciais da Agroanalysis, ele praticamente não aparece e quando é enunciado, geralmente é inglês ("agribusiness"), o termo "agronegócio" é progressivamente adotado em um contexto de evidente euforia com seus resultados econômicos,

24 Este artigo publicado na Agroanalysis sintetiza vários dados sobre a trajetória econômica das atividades agropecuárias no período e é fonte para esta reflexão, demonstrando o quanto a revista tem desempenho naquilo que se propõe a cobrir e a analisar ao apresentar-se como uma revista "científica" ou "técnica". Essa correlação evidente nas páginas da revista só pode ser esclarecida com uma entrevista com editores e colaboradores próximos da Agroanalysis. Mas a euforia dos editoriais e artigos dessa época, trazendo o termo 'agronegócio' em destaque, chama a atenção para esta correlação. 
a ponto de ser qualificado, por Rodrigues, como o "maior negócio do país", na entrevista que enfoca os preparativos e as expectativas em torno do I Congresso da Abag (edição de abril/maio, 2002: 3-5). O próprio editorial da revista embarca nesse entusiasmo trazendo como título, na edição de maio de 2003, a seguinte afirmação sobre o setor no Brasil: "O maior agronegócio do planeta" (p. 9).

Paralelo ao crescimento e visibilidade do seu poder econômico, é possível acompanhar um processo de rearticulação e unificação das lideranças e entidades do setor patronal agrícola ao longo destes dez anos. Uma entrevista de Rodrigues, na edição agosto de 1996 (p. 3-5), já explícita essa intenção, encabeçada justamente por ele, a liderança com mais evidência na revista e que foi se consolidando como representante ao longo deste processo. Esta entrevista tinha como mote o lançamento oficial do Instituto de Estudos do Agribusiness, e nela há um histórico da articulação que então liderava.

Rodrigues conta que a própria $\mathrm{ABAG}$, fundada 1993, era originariamente o projeto do Instituto de Estudos do Agribusiness e que eles agora estavam resgatando essa ideia. Cita como outra origem a Frente Ampla para a Agricultura Brasileira (FAAB), montada em 1987, que congregou OCB, liderada pelo próprio, a CNA, presidida por Alyson Paulinelli, e a SRB, por Flávio Telles de Menezes. Segundo ele, a FAAB tinha como objetivo básico unificar os discursos e as reivindicações em termos de uma política agrícola do complexo agroindustrial, tanto que teve a característica de convocar entidades que não eram agrícolas. Na opinião de Rodrigues, a Frente Ampla, que era algo informal, se constituiu "na semente de uma organização de agribusiness no Brasil". Com a dispersão da Frente Ampla, Ney Bittencourt passou a comandar o "movimento" e a ideia de que era preciso entender melhor o agribusiness brasileiro voltou com força. Foi então que lançaram, em 1991, o livro que divulgou/trouxe o termo "agribusiness". Logo depois, começaram a montar uma associação de agribusiness, que acabou culminando na criação da ABAG em 1993.

Nesta entrevista, fica claro que esse processo atravessou maus momentos como a crise agrícola, o grande prejuízo que tomaram com a feira Agrishow de 1995 e a morte de Bittencourt. Rodrigues menciona inclusive que, no início de 1996, quando se preparava o programa do seminário de lançamento do Instituto, "ninguém sabia o que seria feito da ABAG, se a Agrishow seria um sucesso ou não". Como a Agrishow de 1996, realizada em Ribeirão Preto, resolveu boa parte dos problemas da Abag, se "encheram de coragem para reencetar, para retomar as ações" (Agroanalysis, agosto, 1996: 3).

Na mesma entrevista, Rodrigues se ressente da "falta é um diagnóstico mais rigoroso sobre quem é o agricultor brasileiro hoje. Como dirigente de classe, 
cada vez sei menos quem realmente é aquele que eu represento", diz. Com isso, se pretendia que o Instituto elaborasse um projeto de política agrícola baseado na realidade e não em diagnósticos e "prognósticos de gabinete". E afirma: "Agora o Instituto decola e vamos trabalhar para um projeto nacional, de interesse da nação e não de um ou outro setor". Para ele, o que faltava era "uma base acadêmica para que o posicionamento do setor agrícola e do agribusiness fosse harmonioso, consistente e legítimo". Segundo ele, a proliferação das entidades de classe levou a um descompasso de ideias e proposições para o setor. Com esta constatação é que resolveram montar um instituto privado de estudos de agribusiness, que permitisse formar essa base científica e acadêmica para o discurso das lideranças, "uma base única, de tal forma que teríamos um discurso unificado" (Agroanalysis, agosto, 1996: 3-5).

Esta entrevista descreve de forma clara a plataforma que Rodrigues estava lançado para o setor que então procurava representar, relembrando a importância da Frente Ampla da Agropecuária Brasileira para suas conquistas durante a Constituinte. Para Regina Bruno, a FAAB de fato "representou uma primeira tentativa de organização de alguns setores não necessariamente ligados à atividade agrícola - um dos primeiros passos para a ampliação e redefinição do campo de representação no processo de constituição político do agronegócio" (Bruno, 2009:120). Era uma entidade informal, sem presidente, sem estatuto, mas já congregava cerca de 72 entidades nacionais, empresas de semente, de adubo etc., seguindo a ideia de "constituir uma nova instância de representação patronal mais diretamente ligada ao conjunto das cadeias produtivas e às associações por produto e multiproduto" (Ibid.).

Em entrevista concedida a Bruno (2008), Rodrigues explicou que foi por conta da FAAB que ele começou a participar de diversos conselhos da República, como o Conselho Monetário Nacional, o Conselho Nacional de Política Agrícola, Conselho Nacional de Crédito Rural e Agroindustrial, Conselho de Comércio Exterior. Importante lembrar que Paulinelli, companheiro de Rodrigues na articulação da FAAB, foi ministro da Agricultura do governo Ernesto Geisel na época que foi implantado o Prodecer (Programa de Desenvolvimento do Cerrado) que, com aporte de capital japonês, tornou-se a ponta de lança da estruturação e da expansão da monocultura da soja para a região Centro-Oeste. Ou seja, a configuração agrícola e agrária que estas lideranças expressavam em torno do termo "agronegócio" foi produto de políticas públicas que tiveram o próprio Paulinelli como importante articulador.

Além disso, a FAAB teve um papel muito importante na Constituinte de 1988, na qual compôs o conhecido "Centrão", determinante na derrota do capítulo da 
reforma agrária na Carta Magna brasileira, com retrocessos até em relação ao Estatuto da Terra do regime militar. Segundo Bruno, embora representasse posições mais moderadas com relação à reforma agrária no âmbito do patronato rural, a FAAB acabou alinhando-se "inteiramente" com a União Democrática Ruralista (UDR) contra a reforma agrária e as lutas pela terra (2002: 124). Segundo a autora, "somente nos anos 90, após a vitória política dos grandes proprietários de terra na Constituinte é que Associação Brasileira de Agribusiness (ABAG) vai assumir e pôr em prática a proposta inicial de Paullineli e de seu grupo" (Ibid.), da qual fazia parte Roberto Rodrigues, eclipsados, na época, pela liderança de Ronaldo Caiado, com a UDR.

São vários os artigos e entrevistas de Rodrigues na Agroanalysis, em que a FAAB é mencionada como exemplo de unidade a ser perseguida pelas entidades patronais. Em uma dessas ocasiões, ao assumir sua presidência, diz que pretendia reformular a FAAB, por meio da ABAG, sem o "informalismo daqueles tempos" (Agroanalysis, abril, 1999:3-4). Na época, a revista apresenta os planos dele como "ambiciosos", visto que pretendia que a associação fosse uma espécie de "catalizador entre as entidades do setor, para melhorar a articulação política e de lobby". Sua meta como presidente era lutar "para mudar a imagem do setor rural junto à opinião pública" e buscar o que chamava de "alianças estratégicas" entre os vários segmentos que fazem parte das cadeias produtivas, assegurando benefícios a todos eles". Seu diagnóstico para "a questão da imagem" do setor era a seguinte:

A população em geral, especialmente a urbana, sabe muito pouco sobre a agricultura. E tem um conceito distorcido sobre o agronegócio. Para o consumidor, o agricultor é um profissional despreparado. Não está clara a ideia da cadeia produtiva, que começa na prancheta do pesquisador científico e acaba na gôndola do supermercado, fazendo do consumidor um verdadeiro parceiro do produtor, mas este conceito não existe na cabeça brasileira (Agroanalysis, abril, 1999: 4).

Rodrigues chega a mencionar a intenção de publicar um livro, com apoio da Lei Rouanet, contando a história do Brasil "sob a ótica do agronegócio. No fundo, a verdadeira história do Brasil". Este livro teria como objetivo "mudar o conceito do agronegócio no Brasil, mostrar que a agricultura é a base do processo de desenvolvimento e que todos os setores dependem dela". Pretendia divulgar para a população uma "visão sistêmica do agronegócio brasileiro", ou seja, "uma calça jeans é feita de algodão, que um sapato só existe porque tem boi andando no pasto, a cerveja só existe por conta do produtor de cevada" (Ibid:4). Rodrigues 
tinha em vista a mesma preocupação apontada por Hafers, na entrevista citada na introdução deste trabalho, como podemos ver na seguinte afirmação:

"O cuidado com a imagem do setor é fundamental, porque as políticas públicas num país democrático só são alteradas se a opinião pública concordar. Enquanto a opinião pública desprezar a agricultura, nada mudará" (Idem: 4).

A edição em que foi publicada esta entrevista, abril de 1999, teve na capa a manchete "Dez anos de queda: renda das lavouras brasileira encolhe $38 \%$ nos anos 90, anulando os ganhos de produtividade. Chegou a hora da virada". 0 fato de a desvalorização cambial ter ocorrido em janeiro deu força às intenções da revista, pois esse momento marca o início da arrancada econômica do setor agropecuário que passa a ser um dos únicos superavitários na economia brasileira, tornando-se peça chave na recuperação das reservas do país.

\section{Campanhas eleitorais e as "invasões"}

Em 2002, ano da campanha para as eleições presidenciais, Rodrigues volta a mencionar o "retumbante êxito da Frente Ampla da Agropecuária Brasileira na segunda metade dos anos 80", em seu "Diário de Bordo", devido exatamente à participação, "sob a tríplice coordenação $\mathrm{OCB} / \mathrm{CNA} / \mathrm{SRB}$, de entidades representativas dos setores antes e depois da porteira, incluindo a Febraban (Federação Brasileira de Bancos)". (Agronalysis, outubro, 2002: 66). Neste artigo, anuncia a criação do Conselho Superior de Agricultura e Pecuária do Brasil, conhecido também como "Conselho Rural Brasil”. Sob liderança da CNA, o conselho foi instituído em 14 de agosto de 2002, e funcionaria em sua sede, contando com a participação da $\mathrm{OCB}, \mathrm{SRB}, \mathrm{ABCZ}$ (Associação Brasileira dos Criadores de Zebu), do CNC (Conselho Nacional do Café) e da UBA (União Brasileira de Avicultura) (Agronalysis, outubro, 2002:66). O futuro ministro recorda sua defesa da "unificação do discurso do agribusiness brasileiro em uma espécie de conselho nacional do agronegócio, inteiramente privado, composto pelas entidades de representação das diversas cadeias produtivas". Para ele, a criação do Rural Brasil se justificava porque:

...o agribusiness é mesmo o maior negócio do país, seja em termos de participação do PIB, seja quanto à geração de empregos, seja no que diz respeito às exportações e ao saldo na balança comercial, para não falar da garantia do abastecimento interno com qualidade e competitividade (Agronalysis, outubro, 2002: 66). 
Por esta razão, Rodrigues afirma que "o agribusiness não poderia jamais ser desrespeitado por governantes nem pelos demais setores da economia e seu peso político deveria ser proporcional ao peso socioeconômico". Para ele, sua fraqueza política tinha "razões históricas, determinadas pelo próprio paternalismo estatal do passado que fez florescer ou fenecer diferentes elos das cadeias produtivas, ao sabor de interesses pessoais, ou até mesmo conjunturais, de governos de plantão". Naquele cenário de instabilidade econômica, o setor poderia ser mais penalizado do que outros "por preconceito eventual dos novos governantes, porque está bem posicionado na economia, apesar dos custos terríveis do ajuste no passado, ou por ideologia" (Agronalysis, outubro, 2002: 66).

A liderança de Lula nas corridas presidenciais daquele ano obrigou várias entidades a se rearticular politicamente em torno dessa possibilidade, até então cercada de temores por parte das classes dominantes do país. É provável que essa frase se referia justamente ao possível "preconceito" que haveria da parte de Lula e de seu partido, o PT, com relação ao segmento representado e defendido por Rodrigues. É neste contexto que ele afirma que a união do setor era "fundamental" e que a nova entidade estava surgindo como uma oportunidade, podendo constituir-se "em elemento diferencial nas relações com o Parlamento e até mesmo influenciar a escolha do novo ministro da Agricultura".

Se a criação da "Rural Brasil" aparenta ser o ápice de um processo de articulação de interesses e grupos dominantes do meio rural brasileiro, esse processo na verdade passou por etapas anteriores, como foi o caso do Fórum Nacional da Agricultura, o FNA, e culminou no $1^{\circ}$ Congresso da ABAG, em junho de 2002.

Dois anos mais tarde, já no Governo Lula, o Secretário Nacional de Política Agrícola do MAPA, Ivan Wedekin, declarou que naquele congresso tinha sido feito o planejamento estratégico do Ministério administrado por Rodrigues, "norte" do qual não se "desgarraram" e no qual foi traçada "as políticas para os chamados '10 Cs' da competitividade do agronegócio". Na introdução desta entrevista, a revista afirma que "avançar cada vez mais neste caminho" era "a meta do ministro", com "o total apoio do presidente Lula" (:4). A "prova disso" era que o Plano Agrícola e Pecuário para 2004/2005 estava "concentrado nos três 'Cs' da competitividade: capital, comércio e condução ao mercado" (Agroanalysis, julho 2004:4).

Foi depois da experiência do FNA, já no início do ano eleitoral de 1998, que a Agroanalysis adota em vários artigos uma postura que visa tentar articular os produtores rurais para eleger candidatos comprometidos com os interesses do "agribusiness". Um destes primeiros artigos, de autoria de Rodrigues, trazia como título "Tempo de balanço", com a seguinte chamada na capa "O que 
esperar de 1998, segundo Roberto Rodrigues" (p. 13-14). Nele, o futuro ministro afirma que havia o que comemorar, embora não fosse muito, porque a renda na agricultura havia crescido $5 \%$, devido à soja. Menciona também que estudos oficiais indicavam que 2 e 3 milhões de pessoas perderam o emprego no campo nos últimos cinco anos, fenômeno que, para ele, tinha como causa o crescimento das invasões de terra. Esta "séria questão social" era oriunda de uma "deformação econômica", que foi o fato de que a agricultura havia sido "a âncora verde do Real", que acabou por alimentar "uma questão política que cresceu com a inabilidade do governo: a invasão de terras. (....)”. Para ele:

Invadir terras é um absurdo, um ato de violência ilegal e intolerável, para o qual as autoridades são complacentes. É imperioso acabar com isto, mesmo porque em determinadas regiões do país a prática inibe investimentos no campo. Gera insegurança, medo e ódio. Mas também é preciso desarmar espíritos, promovendo uma reforma agrária que resolva sem demagogia e exageros o problema social. E para isso o sistema cooperativo brasileiro tem propostas que não são levadas em conta (Agroanalysis, janeiro, 1998: 14).

É no final do artigo que o autor menciona que tendo em vista as próximas eleições:

O agribusiness brasileiro precisa se organizar muito bem para escolher candidatos comprometidos com as reformas necessárias para o Executivo e para o Legislativo, na área federal e na área estadual. Afinal, reformas implicam profundas mudanças legais, que serão objeto de grandes acordos entre os poderes. E se o setor não estiver bem representado perderá a oportunidade de avançar (Agroanalysis, janeiro, 1998: 14).

Como vemos, além de preferir usar o termo "agribusiness", Rodrigues manifesta interesse nas reformas (embora não cite quais) que, na época, eram propugnadas pelo governo do Partido da Social Democracia Brasileira (PSDB), chefiado por Fernando Henrique Cardoso. Embora não assuma claramente uma posição a favor de eleições de políticos do PSDB, pode-se observar que o único candidato a deputado entrevistado pela revista ao longo deste ano, o presidente da Garcafé (Cooperativa dos Cafeicultores da Região de Garça, SP), Manuel Vicente Bertone, concorria a deputado federal por esta legenda. Apresentado pela Agroanalysis como "típico dirigente moderno", Bertone recebeu três páginas da revista para apresentar suas propostas. Sua entrevista, por sinal, traz a mais contundente crítica à forma como o MST implementava a luta pela terra. Para ele, os anos anteriores se pautaram pelo fato de que "houve mais 
produtores que quebraram e venderam suas terras para pagar juros absurdos do que o número de assentados pela reforma agrária. E quem quebrou produzia por meio de investimentos próprios, com grandes riscos e sem custos para o contribuinte". Embora garanta que considerava importante a reforma agrária para se "acabar com a miséria", as críticas de Bertone às invasões foram as mais contundentes até então publicadas:

Hoje as invasões estão levando à morte de inocentes, causando pânico nas regiões escolhidas pelo movimento, acabando com o valor das propriedades e com a capacidade de investimento e a vontade de trabalhar do agricultor. (...)Sou absolutamente contra invasões de propriedades privadas e critérios injustos de desapropriação e de pagamento dos proprietários. Hoje são terras, amanhã serão nossas casas, as indústrias, estabelecimentos comerciais e assim por diante (Agroanalysis, abril, 1998: 4-5).

Na segunda gestão de FHC, que começa em 1998, observa-se na Agroanalysis que a articulação dos produtores rurais encabeçada por Rodrigues fica frustrada com a não implementação das definições do FNA, embora tenha sido nomeado um ministro da Agricultura, Pratini de Moraes, cuja gestão, agressiva em termos de promoção e defesa dos produtos agropecuários nos meios internacionais, tenha sido elogiada e fosse uma referência para o setor, conquistando destaque na revista. Esta insatisfação com o governo do PSDB fica evidente na coluna "Diário de Bordo", de Rodrigues, então presidente da ABAG, na edição de fevereiro de 2002, portanto no ano eleitoral seguinte (p. 50), em que critica o governo FHC em vários pontos. Dentre eles, a falta de "garantia de direitos básicos como o de propriedade e o de segurança individual e coletiva”, tratados de forma secundária, "como se não houvesse convicção clara a respeito de tão importantes questões". Além disso, para ele, o "governo central” também havia feito "bem pouco em defesa da agricultura", inclusive não tendo implementado "pontos propostos no Fórum Nacional da Agricultura, criado pelo próprio presidente". Atribui todas as conquistas que o setor obteve nos últimos anos "unicamente à visão dos ministros da Agricultura, particularmente a Pratini de Moraes". E conclama: "Com espírito desarmado, cabe aos produtores rurais e do agronegócio uma posição una e firme para as próximas eleições”. Para presidente, governador, senador, deputado federal ou estadual, "é preciso votar em pessoas que tenham clareza das legítimas demandas do agribusiness" (Agroanalysis, fevereiro, 2002: 50).

Assim, como em 1998, mas agora usando o termo abrasileirado, Rodrigues novamente convoca as "entidades do agronegócio" a preparar "um plano de 
governo para o setor e submetê-lo aos candidatos". A frase de Rodrigues, reiterando que "nossos interesses rurais" são "os interesses reais do Brasil inteiro" revela de maneira clara o mecanismo ideológico construído em torno da articulação política promovida pela Agroanalysis em suas edições ao longo de dez anos de circulação. Se de 1994 a 1998, vemos um setor acuado pelo Plano Real, a queda dos preços agrícolas e a abertura comercial, a situação muda com a desvalorização cambial de 1999. A partir dali, ele começa a se recuperar, o que legitima o discurso que associa o agronegócio aos interesses do país, reiterado pela revista.

Por outro lado, é importante pontuar, o quanto a posição da revista em 1998, tanto na entrevista de Rodrigues, de janeiro, como na entrevista com Bertone, em abril, apresentam posições francamente contrárias à forma como os movimentos sociais do campo lutavam por reforma agrária, o que efetivamente garantiu a maioria das desapropriações de imóveis rurais para a reforma agrária no país. Segundo Fernandes (2010), cerca de 85\% dos assentamentos no Brasil foram criados mediante as ocupações de terra desde a década de 80. Não por acaso, 1998 é um dos anos que mais registra ocupações no país. Ou seja, a revista dá voz a uma franca oposição à forma com efetivamente se dava a reforma agrária naquele contexto, embora ainda aposte na possiblidade de o PSDB vir a representar melhor o grupo de interesse que eles conformavam em torno do termo agronegócio, até por que o PT na época, principal rival desta legenda, era conhecido publicamente por apoiar as ocupações promovidas pelos movimentos sociais do campo. No entanto, justamente um dos representantes mais destacados do setor que sempre se opôs às "invasões de terra", torna-se ministro da Agricultura do primeiro Governo Lula e leva consigo os sentidos que ao longo da década anterior foram sendo construídos e disputados em torno desta nova palavra: agronegócio.

\section{Conclusão}

A introdução de um neologismo no léxico usado no espaço público de qualquer sociedade se dá em etapas e geralmente revela novas configurações sociais associadas ao novo termo. Este é o caso de "agronegócio", tradução abrasileirada do termo "agribusiness".

Entre 1994 e 2004, o grupo de interesse que se articulou em torno da Agroanalysis procurou divulgar e tornar reconhecido tanto o termo agronegócio, como a legitimidade das demandas a ele associadas. Nas páginas da revista, 0 termo "agronegócio" foi tornando-se uma forma de classificação, uma categoria 
social de entendimento sobre fenômenos associados à produção agropecuária brasileira em intensa transformação e crescente rentabilidade. A palavra agronegócio, como qualquer fenômeno da linguagem, embute pré-construções naturalizadas, portanto ignoradas como tal, mas que funcionam como instrumentos inconscientes de construção da percepção do mundo social e que, por sua vez, adotado por determinados atores oriundos de grupos dominantes do meio rural brasileiro teve o poder não só de se legitimar como expressão, como promover efeitos econômicos e políticos na sociedade por meio do uso deste termo, hoje parte do léxico referente a questões do meio rural brasileiro (Elias, 2006).

Quando a revista Agroanalysis deu publicidade ao conceito agribusiness e mais tarde agronegócio, tornou-se um espaço de "exposição social de fenômenos, intenções, planos e atualidades que se oferecem ao conhecimento de todos" (Maya, 2004:4), primeiro passo para que uma determinada questão passe a ser objeto de "deliberação pública" (ibidem) e, a seguir, seja então consagrada tanto por políticas públicas, como por sua incorporação ao léxico de atores em um debate público mais generalizado. A Agroanalysis foi, portanto, o palco de um trabalho de produção e imposição de novas representações sobre o rural, levando consigo a consagração de alguns de seus agentes, com sua ascensão ao MAPA, assim como a bem-sucedida imposição de um novo termo dentro do léxico comum e usual dos brasileiros.

Para Bruno (2009: 114), agronegócio é uma "palavra política", mais especificamente uma "palavra unificadora de interesses das classes e grupos dominantes no campo e expressão do processo de construção da hegemonia e de renovação dos espaços de poder e de dominação". É, portanto, uma expressão que contribui para dar legitimidade às práticas dos grupos dominantes do meio rural brasileiro e é esse processo que vimos estampado nitidamente na Agroanalysis. Ao publicar, por exemplo, edições especiais sobre a expansão da produção agrícola no Mato Grosso (julho, 2001: 7-44), no Maranhão (novembro, 2001: 11-28) e em Goiás (janeiro, 2002: 3-10 e 14-28), a revista contribuiu para difundir o termo, construindo um espaço de visibilidade para o termo "agronegócio" e, assim, para a criação de uma base reflexiva para a deliberação e para a constituição de um grupo de interesse formado por lideranças do setor patronal da agricultura brasileira. Este processo, ao modelar este discurso unificador, provavelmente foi o que construiu as bases para a indicação política deste grupo para o Ministério da Agricultura, tornando-o fonte oficial.

Evidentemente que a força política do "agronegócio" se respaldou em sua força econômica, pois, como observou Bacha, em artigo da Agroanalysis (junho, 2004: 23), a abertura econômica brasileira na década de 1990 permitiu uma 
melhoria nos preços agrícolas versus preços industriais. Em 1999, a relação dos preços agrícolas/preços industriais foi 146\% superior à de 1989. Ou seja, além do crescimento da produtividade e do aumento das exportações, um aspecto não esperado da conjuntura econômica criada com a estabilização monetária realizada em 1994 foi o aumento do preço das commodities agrícolas em relação aos preços dos produtos industriais brasileiros.

No entanto, o início da articulação deste grupo de interesse associado ao termo "agronegócio" se deu em um período de grandes dificuldades econômicas e políticas para o setor, acuado pela "imagem antiga" que tinha perante a opinião pública e pelo aumento da luta pela terra no país, que então galvanizava bastante simpatia. Entretanto, por ser um grupo de interesse associado ao capital agrícola e a uma elite política, esta articulação demonstrou estar em uma posição de poder privilegiada a ponto de determinar os rumos da política agrícola e, porque não dizer, agrária, quando houve uma mudança de governo. É importante ressaltar que este grupo teve como principal porta-voz Rodrigues, que, além de ter sido Secretário da Agricultura do Estado de São Paulo, ocupou a direção de entidades do setor, como OCB e SRB. O capital simbólico acumulado por este grupo frente ao governo do PT, que se iniciava, era derivado de uma relação de poder historicamente anterior ao fato de ter começado a se organizar para promover ações coletivas e a unificar um discurso. Esta capacidade política foi construída por meio de iniciativas do passado, como a articulação da FAAB, durante a Constituinte, a fundação da $\mathrm{ABAG}$, e a mais recente articulação do FNA, processo que culminou no $1^{\circ}$ Congresso da $A B A G$, em que foram estabelecidas as metas que Rodrigues procurou implementar no MAPA. Esta articulação e composição política se expressa e se realiza nas páginas da revista, construindo-se em torno da produção de uma nova categoria de classificação e de representação para fenômenos ligados à grande produção de commodities no meio rural brasileiro, sintetizada no termo agronegócio.

Apesar desta posição privilegiada, a articulação do grupo de pressão, responsável pela entronização do termo agronegócio no léxico do brasileiro, construiu uma visão bastante negativa do governo FHC, por seu suposto apoio às invasões de terra. Em meio a uma entrevista sobre a crise do cafée, o então presidente da Comissão do Café da CNA, em 2002, João Roberto Pulitti, afirmou que o governo FHC foi tão ruim "como o de João Goulart".

26 Entrevista concedida em julho de 2002, na região de Varginha que fez parte da pesquisa realizada por mim e por Dauro Veras para o relatório "Café do Brasil - O gosto amargo da crise”. Florianópolis: Observatório Social. 
Mesma visão foi apresentada pelo então presidente da SRB, João de Almeida Sampaio Filho, em entrevista concedida em 2003. Para ele, "seguindo o apoio da mídia, o governo FHC fez a maior e talvez uma das piores reformas agrárias do mundo ${ }^{27}$ ”. Ou seja, a luta pela terra e pela reforma agrária e sua visibilidade no espaço público fragilizava politicamente o setor, já atormentado pela desmontagem das políticas agrícolas do Governo Federal, forte redução do sistema de crédito rural público e enfrentando a paridade cambial do real com o dólar, que retirou competitividade das exportações de commodities até 1999.

Outro aspecto a se destacar neste processo de articulação política, por meio da promoção do "agronegócio" no país, é a importância que seus porta-vozes deram à construção de uma base científica que chancelasse essa proposição. Isso começou com a publicação do livro capitaneado por Araújo, em 1991, e teve seguimento na fundação do Instituto de Estudos do Agribusiness e nas páginas da Agroanalysis, revista editada por uma entidade de ensino de prestígio como a FGV. Gryinzpan (2012) demonstra que a universidade, no caso as norte-americanas Iowa e Harvard, também estiveram presentes na difusão do conceito agribusiness. Apesar de um estudo sobre a participação do agronegócio no PIB, publicado pela revista, ter desmentido um dos grandes slogans deste grupo liderado por Rodrigues, ao demonstrar que o agronegócio não representava $32 \%$, e $\operatorname{sim} 20,6 \%$ do PIB (Agroanalysis, novembro, 2000:42-43), manteve-se a afirmação da busca pela "base acadêmica" para que, nas palavras de Rodrigues, em sua primeira entrevista à Agroanalysis, "o posicionamento do setor agrícola e do agribusiness fosse harmonioso, consistente e legítimo". Esta frase dele, engenheiro agrônomo e professor universitário da UNESP de Jaboticabal ${ }^{28}$, sintetiza os objetivos de unificar o discurso do setor por meio da chancela científica proporcionada pela revista da FGV.

Ao longo desta trajetória editorial, a Agroanalysis congregou em suas páginas uma série de pesquisas relevantes e informativas sobre a agricultura brasileira, emprestando mais legitimidade para o discurso político que promovia e que, de fato, pautou o salto que se consubstanciou na ida de Rodrigues para o Ministério da Agricultura, período no qual o termo "agronegócio" conquistou sua efetiva consagração pública. Por outro lado, é inegável que com a afirmação do agronegócio, as lutas pela terra e pela reforma agrária e o discurso que

27 Entrevista concedida para esta autora para o livro "Reforma Agrária: os caminhos do impasse", Editora Garçoni, 2003, SP, p. 164.

28 Na atualidade, Rodrigues coordena o Centro de Agronegócios da FGV. 
as sustentavam perderam eficácia no espaço público ${ }^{29}$. Já a nova imagem dos "produtores rurais", para convencer a opinião pública, como citada por Hafers, e para explicar como todos os setores da economia brasileira dependem da agricultura, como queria Rodrigues, sintetizou-se no termo agronegócio e se cristalizou nas inserções publicitárias bancadas pela TV Globo sob o título, "o agro é pop, o agro é tech, o agro é tudo". No entanto, Rodrigues e o setor que representa sempre condenaram as "invasões" de terra, forma predominante pela qual as populações pobres do campo tiveram acesso à terra nos últimos 30 anos.

\section{Referências}

ALIMANDRO, Regis; PINAZZA, Luiz Antonio. Entrevista com Roberto Rodrigues "O PCCA chega ao poder". Agroanalysis, v. 22, n. 10, fevereiro-março 2003, pp. 3-7.

ALIMANDRO, Regis. Entrevista com Ivan Wedekin: "Agronegócio é uma mistura de realismo e entusiasmo". Agroanalysis, v. 24, n. 7, Julho 2004, pp. 4-6.

ALMEIDA, Alfredo Wagner Berno de. Agroestratégias e desterritorialização: direitos territoriais e étnicos na mira dos estrategistas dos agronegócios. In: ALMEIDA, Alfredo Wagner Berno de et al. Capitalismo globalizado e recursos territoriais. Rio de Janeiro, Lamparina, 2010, pp. 101-143.

ANDRADE JÚNIOR, José Roberto Porto de. Onde tem fumaça tem fogo. São Paulo, Editora Fap-Unifesp, 2016.

BACHA, Carlos José Caetano. O sucesso da agropecuária brasileira. Agroanalysis, v. 24, n. 6, Junho 2004, p. 23.

BERTONE, Manuel Vicente. Entrevista "Exportar imposto não é nada inteligente". Agroanalysis, v. 18, n. 4, Abril 1998, pp. 4-5.

BOURDIEU, Pierre. O poder simbólico. Lisboa, Difel, 1989.

BRESSER PEREIRA, Luiz Carlos. Entrevista "Modelo para o mundo". Agroanalysis. Rio de Janeiro, v. 19, n. 8, Agosto 1999, pp. 3-4.

BRUNO, Regina. O ovo da serpente: monopólio da terra e violência na Nova República. Tese de Doutorado, Ciências Sociais, Unicamp, 2002.

BRUNO, Regina. Entrevista de Roberto Rodrigues à Regina Bruno em São Paulo 13 de agosto de 2008. Íntegra. Gentilmente cedida pela autora.

BRUNO, Regina Angela Landim. Um Brasil Ambivalente. Agronegócio, Ruralismo e Relações de Poder. Mauad X e Edur-UFRRJ. Rio de Janeiro, v. 1, 2009.

29 Em artigo de 2003, em que faz um balanço da política agrária do Governo FHC, Martins antecipa como os governos petistas lidaram com a questão agrária brasileira: "o PT incorporou o tema da reforma agrária no elenco de seus assuntos, mas não o assimilou nem tentou compreendê-lo além do imediatismo partidário, como efetiva matéria de governo e de administração política das contradições sociais” (p. 145). 
CARDOSO, Fernando Henrique. Entrevista "O mercado não pode ser fator de exclusão". Agroanalysis, v. 17, n. 10, Outubro 1997, pp. 1-3.

COMPARATO, Bruno Konder. A ação política do MST. São Paulo, Expressão Popular, 2000.

CONTINI, Eliseu; NUNES, Eduardo Pereira. Passando a limpo. Agroanalysis, v. 20, n. 11, Novembro 2000, pp. 42-49.

DIAS, Guilherme Leite da Silva. Entrevista "As diretrizes da nova política agrícola”. Agroanalysis, v. 15, n. 1, Janeiro 1995, p. 7.

DELGADO, Guilherme. A Questão Agrária e o Agronegócio no Brasil. In: CARTER, Miguel. Combatendo a desigualdade social: O MST e a Reforma Agrária no Brasil. São Paulo, Editora Unesp, 2010, pp. 81-112.

EDITORIAL “A dívida e o futuro". Agroanalysis, v. 15, n. 6, Junho 1995, p. 7.

EDITORIAL. Agronalysis. Rio de Janeiro, v. 24, n. 10, Outubro 2004, p. 7.

EDITORIAL. Agroanalys, v. 17, n. 6, Junho 1997, p. 6.

EDITORIAL “Carta Verde”. Agroanalysis, v. 15, n. 5, Maio 1995, p. 7.

EDITORIAL “Página Virada”. Agroanalysis, v. 15, n. 8, Agosto 1995, p. 7.

EDITORIAL "Um sonho à frente do nosso tempo". Agroanalysis, v. 22, n. 10, dezembro-janeiro, p. 7.

ELIAS, Norbert. La société des individus. Paris, Fayard, 2006.

ESPECIAL Goiás. Agroanalysis, v. 22, n. 1, Janeiro 2002, pp. 3-10 e pp. 14-28.

ESPECIAL Maranhão, Agroanalysis, v. 21, n. 11, Novembro 2001, pp. 11-28.

ESPECIAL Mato Grosso. Agroanalysis, v. 21, p. 7, Julho 2001, pp. 8-44.

FERNANDES, Bernardo Mancano. Formação e Territorialização do MST no Brasil. In: CARTER, Miguel. Combatendo a desigualdade social: O MST e a Reforma Agrária no Brasil. São Paulo, Editora Unesp, 2010, pp. 161-197.

FÓRUM Nacional da Agricultura: conversação de paz. Agroanalysis, v. 17, n. 7, Julho 1997, pp. 19-26.

GAMEIRO, Mariana B. P. O Fetiche da Mercadoria "Verde": a questão ambiental na construção social da imagem do etanol brasileiro. Tese de Doutorado, Sociologia, UFSCar, 2017.

GERMANI, Luiz Augusto. Reforma Agrária em ambiente produtivo. Agroanalysis. Rio de Janeiro, v. 24, n. 8, Agosto 2004, p. 48.

GERMANI, Luiz Augusto. Proteção à propriedade. Agroanalysis. Rio de Janeiro, v. 23, n. 6, Setembro 2003, pp. 12-14.

GRYNSZPAN, Mário. A afirmação do agronegócio: novos agentes e representações do rural. Caxambu, Anais Anpocs, 2009.

GRYNSZPAN, Mário. Origens e conexões norte-americanas do agribusiness no Brasil. Revista Pós Ciências Sociais, v. 9, 2012, pp. 123-148. 
HAFERS, Luiz Suplicy. Entrevista. Agroanalysis. Rio de Janeiro, v. 18, n. 2, Fevereiro 1998, pp. 3-5.

MARTINS, José de Souza. A reforma agrária no segundo mandato de Fernando Henrique Cardoso. Tempo Social (Revista de Sociologia da USP). São Paulo, v. 15, n. 2, 2003, pp. 141-175.

MAYA, Rousiley Celi Moreira. Dos dilemas da visibilidade midiática para a deliberação pública. In: LEMOS, André. [et al]. (Org.). Livro da XII Compós: Mídia.BR. 1 ed. Porto Alegre, Sulina, 2004, pp. 9-38.

MENDONÇA, Sonia Regina de. O Patronato Rural Brasileiro na Atualidade: dois estudos de caso. Anuario del Centro de Estudios Históricos Profesor Carlos S. A. Segreti, V. 8, 2010, pp. 139-159.

LERRER, Débora Franco. Reforma Agrária: os caminhos do impasse. São Paulo, Editora Garçoni, 2003.

OFFE, Claus; WIESENTHAL, Helmut. Duas lógicas da ação coletiva: notas teóricas sobre a classe social e a forma de organização. In: OFFE, Clauss. Problemas Estruturais do Estado Capitalista. Rio de Janeiro, Tempo Brasileiro, 1984.

PINAZZA, Luiz Antonio. Os novos paradigmas para a reforma agrária. Agroanalysis. Rio de Janeiro, v. 16, n. 2, Fevereiro 1996, pp. 20-21.

RETRATO em família. Agroanalys, v. 20, n. 9, Setembro 2000, pp. 31-40.

RIBEIRO NETO, Caio Pompeia. A Concertação Política do Agronegócio. Tese de Doutorado, Antropologia Social, Tese de Doutorado, Antropologia Social, Unicamp, 2018.

RODRIGUES, Roberto. Eleições e propostas. Agroanalysis, v. 22, n. 2, Fevereiro 2002, p. 50. RODRIGUES, Roberto. Entrevista "Redescobrindo a agricultura brasileira”. Agroanalysis, v. 16, n. 8, Agosto 1996, pp. 1-4.

RODRIGUES, Roberto. Entrevista "Reformas estruturais para a agricultura". Agroanalysis, v. 15, n. 6, Junho 1995, pp. 1-2.

RODRIGUES, Roberto. Entrevista "Revolução silenciosa”. Agroanalysis, v. 19, n. 4, Abril 1999, pp. 3-5.

RODRIGUES, Roberto. Tempo de Balanço. Agroanalysis. Rio de Janeiro, v. 18, n. 1, Janeiro 1998, pp. 13-14.

RODRIGUES, Roberto. Um grande passo. Agronalysis, v. 22, n. 8, Outubro 2002, p. 66.

SILVA, Marina da. No rastro da incerteza Agroanalysis. Rio de Janeiro, v. 19, n. 8, Agosto 1999, pp. 64-65.

VERAS, Dennis; LERRER, Debora Franco. Café do Brasil - O gosto amargo da crise. Florianópolis: Observatório Social, (Relatório), 2002.

YAMAUTI, Laércio. Compromisso com o agribusiness e com o futuro. Agroanalysis. Rio de Janeiro, v. 14, n. 3, Novembro 1994, p. 48. 
Recebido em: 04/09/2018

Aprovado em: 20/03/2020

\section{Como citar este artigo:}

LERRER, Débora Franco. Revista Agroanalysis: a trajetória da afirmação do "agronegócio" e de consagração de seus agentes. Contemporânea - Revista de Sociologia da UFSCar, v. 10, n. 1, jan.- abril 2020, pp. 273-304. 